\title{
A Study of Single Nucleotide Polymorphisms of Tumour Necrosis Factor $\alpha-1031$ and Tumour Necrosis Factor $\beta+252$ in Chronic Rhinosinusitis
}

\author{
Khairunnisak Misron ${ }^{1}$. Suzina Sheikh Ab Hamid · Azlina Ahmad² · Ramiza Ramza Ramli ${ }^{1}$ \\ ${ }^{1}$ Department of Otorhinolaryngology-Head \& Neck Surgery, School of Medical Sciences, Universiti Sains Malaysia Health Campus, Kelantan; \\ ${ }^{2}$ Basic Science and Oral Biology Unit, School of Dental Sciences, Universiti Sains Malaysia Health Campus, Kelantan, Malaysia
}

Objectives. This case-controlled study aimed to identify the association of tumor necrosis factor (TNF) $\alpha-1031$ and TNF $\beta+$ 252 gene polymorphisms between chronic rhinosinusitis (CRS) and healthy controls. Another purpose of this study was to investigate the associations of these gene polymorphisms with factors related to CRS.

Methods. All deoxyribonucleic acid (DNA) samples were genotyped for TNF $\alpha-1031$ and $T N F \beta+252$ genes by mean of polymerase chain reaction (PCR) and restriction fragment length polymorphisms (RFLP). The statistical analysis were carried out using chi-square test or Fisher exact test to determine the associations of these gene polymorphisms in CRS. Multiple logistic regression was performed to evaluate the associations of these gene polymorphisms in CRS and its related risk factors.

Results. The genotype and allele frequencies of $T N F \alpha-1031$ and $T N F \beta+252$ gene did not show any significant associations between CRS and healthy controls. However, a significantly statistical difference of $T N F \alpha-1031$ was observed in CRS participants with atopy ( $P$-value, 0.045 ; odds ratio, 3.66$)$ but not in CRS with asthma or aspirin intolerance.

Conclusion. Although the presence of $T N F \alpha-1031$ and $T N F \beta+252$ gene polymorphisms did not render any significant associations between CRS and healthy control, this study suggests that $T N F \alpha-1031$ gene polymorphisms in CRS patients with atopy may be associated with increase susceptibility towards CRS.

Keywords. Rhinosinusitis; Tumour Necrosis Factors; Single Nucleotide Polymorphism

\section{INTRODUCTION}

Chronic rhinosinusitis (CRS) is one of the commonest upper respiratory tract diseases encountered by otorhinolaryngologists as well as primary care physicians. The Global Allergy and Asthma Network of Excellence (GA2LEN) conducted a survey based on European Position Paper on Sinusitis (EPOS) criteria in 19 centres in Europe found that the prevalence of CRS by

\footnotetext{
- Received December 27, 2016

Revised March 15, 2017

Accepted April 3, 2017

- Corresponding author: Khairunnisak Misron

Department of Otorhinolaryngology-Head \& Neck Surgery, School of

Medical Sciences, Universiti Sains Malaysia Health Campus, 16150 Kubang

Kerian, Kelantan, Malaysia

Tel: +60-9-767-6428, Fax: +60-9-767-6424

E-mail: nis875@gmail.com
}

EPOS criteria was $10.9 \%$ [1]. The role of atopy in the development of CRS has been discussed extensively in the literature in which approximately half of the patients with CRS have positive skin prick test [2]. In addition, the concept of 'one airway, one disease' proposed the relationship between CRS and asthma $[3,4]$. Another factors related to CRS is acetylsalicylic acid (ASA) intolerance. Previous study demonstrated $36.0 \%$ of patients with aspirin intolerance had concurrent nasal polyps [5].

Mucosal oedema and retention of secretion due to blockage of paranasal sinus ostia is the key to the inflammatory response in CRS. This mucosal irritation of airway epithelium triggers the production of numerous proinflammatory cytokines. Although various cytokines have been proven to play pivotal roles in pathogenesis of CRS, this study concentrated on tumour necrosis factor (TNF). In 1985, Aggarwal et al. [6] was the first who defined 2 distinct types of TNF, which are TNF $\alpha$ and lymphotox-

Copyright @ 2017 by Korean Society of Otorhinolaryngology-Head and Neck Surgery.

This is an open-access article distributed under the terms of the Creative Commons Attribution Non-Commercial License (http://creativecommons.org/licenses/by-nc/4.0)

which permits unrestricted non-commercial use, distribution, and reproduction in any medium, provided the original work is properly cited. 
in or also known as TNF $\beta$.

Despite being one of the most prevalent diseases worldwide, the pathogenesis of CRS is still not well understood and appears to be an interaction between environmental and genetic factors. Single nucleotide polymorphisms (SNPs) are defined as genetic variation in deoxyribonucleic acid (DNA) where a single nucleotide is being replaced by another, either by substitution or deletion. The association of SNPs and human disease is complex. Identification of large number of SNPs across human genome has brought the attention of the genetic association studies with common human diseases in a population because common population shares similar genetic variances [7].

The influence of TNF gene polymorphisms in many inflammatory diseases has been addressed in the literatures [8]. The TNF gene polymorphisms have been associated with many chronic inflammatory conditions including rheumatoid arthritis, inflammatory bowel disease and hepatitis B virus infection [911]. It has becomes evidence that $T N F \alpha$ antagonists are effective in the treatment for rheumatoid arthritis. Etanercept and Infliximab demonstrated significant improvement of the symptoms in affected patients [12].

Based on growing evidence on the influence of TNF gene polymorphisms in inflammatory diseases, we aimed to determine the association of $T N F \alpha-1031$ and $T N F \beta+252$ gene polymorphisms between CRS and healthy controls in this study. Besides, we would like to identify the associations of these genes with factors related to CRS.

\section{MATERIALS AND METHODS}

\section{Ethical approval}

This study had been approved by Human Research Ethics Committee, Universiti Sains Malaysia (Federalwide Assurance Registration No. 00007718; Institutional Review Board No. 00004494).

\section{Sample size calculation}

Sample size was determined based on previous literature review by Takeuchi et al. [13] by using PS software ver. 3.1.2, 2014. The power of study was 0.80 with level of statistical significant $(\alpha)$ of 0.05 . The exposure among control (healthy participants) was estimated to be 0.56 and exposure among case (CRS participants) was 0.83 . The sample size calculation was added with $10 \%$ drop

\section{H I G H L I G H T S}

- Tumor necrosis factor (TNF) $\alpha-1031$ and TNF $\beta+252$ gene polymorphisms did not render any significant associations in chronic rhinosinusitis (CRS).

- $T N F \alpha-1031$ gene polymorphisms was significantly associated with CRS participants with atopy. out. Therefore, the sample size was 48 participants for cases and 48 participants for controls in order to accept the alternative hypothesis that there is association between TNF gene polymorphisms and CRS and also control.

\section{Case selection}

A total of 48 participants with CRS (comprised of 24 chronic rhinosinusitis without nasal polyp [CRSsNP] and 24 chronic rhinosinusitis with nasal polyp [CRSwNP]) were recruited from ORL-HNS Clinic, Hospital Universiti Sains Malaysia following criteria as proposed by European Position Paper on Rhinosinusitis and Nasal Polyps 2012 [14]. A standardised questionnaire determining the demographic characteristics including age, gender, and ethnic origin were obtained and shown in Table 1. Symptoms of CRS which comprised of nasal blockage, rhinorrhea, post nasal drip, facial pain, headache, and loss of smell as well as duration of symptoms were recorded. The presence of asthma, allergy, and ASA intolerance were made primarily by patient's history. All cases were subjected to general otorhinolaryngologic examination and nasoendoscopic examination. Written consent were taken from all participants.

\section{Control selection}

The control groups included 48 healthy volunteers who were not blood-related to the cases were drawn from cases' friends and spouses. In order to reduce potential environmental bias, the controls were selected from the same district as the cases. A standardised questionnaire determining the demographic characteristics including age, gender, and ethnic origin were taken as depicted in Table 1 . They had neither any nasal diseases nor family history of CRS at the time of enrollment. All of them underwent general otorhinolaryngologic examination and had normal nasoendoscopic findings. Written consent were taken from all participants.

\section{DNA extraction}

Buccal swab samples were obtained by scrapping the swab firmly against the buccal mucosa and stored at $-20^{\circ} \mathrm{C}$ before DNA extraction was carried out. Extraction of genomic DNA was obtained using Exgene Blood SV Mini (GeneAll, Seoul, Korea).

\section{Polymerase chain reaction (PCR) and restriction fragment length polymorphism (RFLP) for TNF $\alpha$-1031}

The identification of SNPs in the promoter region of TNF $\alpha-1031$ (rs1799964) was determined using modified protocol as previously described [15]. For amplification of the polymorphic sequence, $0.5 \mu \mathrm{M}$ forward primer 5'-GGGGAGAACAAAAGGATAAG-3' and $0.5 \mu \mathrm{M}$ reverse primer 5 -CCCCATACTCGACTTTCATA-3' (First BASE Laboratories, Selangor, Malaysia) were mixed together with $5 \mu \mathrm{L}$ distilled water, $10 \mu \mathrm{L} 2 \times$ Phusion PCR Master Mix with High-Fidelity buffer (Thermo Fisher Scientific, Waltham, MA, USA) and $3 \mu \mathrm{L}$ genomic DNA. The PCR was carried out and the 
Table 1. Demographic characteristic of CRS participants and controls

\begin{tabular}{|c|c|c|c|c|c|c|}
\hline Demographic characteristic & CRS $(n=48)$ & Control $(n=48)$ & $P$-value & CRSsNP $(n=24)$ & CRSWNP $(n=24)$ & $P$-value \\
\hline Sex & & & 0.399 & & & 0.242 \\
\hline Male & 20 & 16 & & 8 & 12 & \\
\hline Female & 28 & 32 & & 16 & 12 & \\
\hline Race & & & 0.789 & & & 0.350 \\
\hline Malay & 40 & 42 & & 21 & 19 & \\
\hline Chinese & 6 & 5 & & 3 & 3 & \\
\hline Indian & 2 & 1 & & 0 & 2 & \\
\hline Age $(y r)$, mean $\pm S D$ & $48.0 \pm 14.8$ & $41.0 \pm 11.7$ & 0.012 & $43.3 \pm 14.9$ & $52.6 \pm 13.5$ & 0.028 \\
\hline Atopy & & & - & & & 0.131 \\
\hline Yes & - & - & & 18 & 13 & \\
\hline No & - & - & & 6 & 11 & \\
\hline Asthma & & & - & & & 0.526 \\
\hline Yes & - & - & & 8 & 6 & \\
\hline No & - & - & & 16 & 18 & \\
\hline ASA intolerance & & & - & & & 0.551 \\
\hline Yes & - & - & & 2 & 1 & \\
\hline No & - & - & & 22 & 23 & \\
\hline
\end{tabular}

CRS, chronic rhinosinusitis; CRSsNP, chronic rhinosinusitis without nasal polyp; CRSwNP, chronic rhinosinusitis with nasal polyp; SD, standard deviation; ASA, acetylsalicylic acid.

cycling condition included initial denaturation at $98^{\circ} \mathrm{C}$ for $30 \mathrm{sec}-$ onds, a total of 30 cycles of denaturation at $98^{\circ} \mathrm{C}$ for 10 seconds, annealing at $55^{\circ} \mathrm{C}$ for 30 seconds and extension at $72^{\circ} \mathrm{C}$ for 10 seconds followed by final extension step at $72^{\circ} \mathrm{C}$ for 10 minutes. Subsequently, fragment length polymorphism (RFLP) was determined by digestion with restriction enzymes BbsI (New England Biolabs, Hitchin, UK) which cuts the 5'-CCATGG-3' and 3'-CTTC TG-5' sequence. A 2.7 $\mu \mathrm{L}$ PCR product were digested with $0.3 \mu \mathrm{L}$ BbsI restriction enzyme together with $10.5 \mu \mathrm{L}$ distilled water and $1.5 \mu \mathrm{L} 10 \times$ NEBuffer. The mixture was incubated at $37^{\circ} \mathrm{C}$ for 10 minutes. Seven microlitres of reaction mixture was added to $3 \mu \mathrm{L}$ $10 \times$ BlueJuice Gel Loading buffer (Invitrogen, Carlsbad, CA, USA) and loaded into the gel. The digestion products were separated on $2.5 \%$ agarose gel which stained with SYBR Safe DNA gel stain (SBS Genetech, Beijing, China) at $80 \mathrm{~V}$ for 50 minutes.

\section{PCR and RFLP for $T N F \beta+252$}

The promoter region containing the $T N F \beta+252$ polymorphisms (rs909253) were amplified by PCR using $0.5 \mu \mathrm{M}$ of $5^{\prime}$-CCGTGCTTCGTGCTTTGGACTA-3' as forward primer and 5'-AGA GCTGGTGGGACATGTCTG-3' as reverse primer (SBS Genetech, Beijing, Chin) as described by Takeuchi et al. [13]. The PCR amplification of the TNF $\beta+252$ polymorphisms was carried out in $20 \mu \mathrm{L}$ volume consisting of $5 \mu \mathrm{L}$ distilled water, $10 \mu \mathrm{L} 2 \times$ Phusion PCR Master Mix with High-Fidelity buffer (Thermo Fisher Scientific), $1 \mu \mathrm{L}$ forward and reverse primers each and also $3 \mu \mathrm{L}$ genomic DNA. The cycle parameters consisted of initial denaturation at $98^{\circ} \mathrm{C}$ for 30 seconds, followed by 30 cycles of denaturation at $98^{\circ} \mathrm{C}$ for 10 seconds, annealing at $65^{\circ} \mathrm{C}$ for 20 seconds and extension at $72^{\circ} \mathrm{C}$ for 5 seconds with a final extension step at $72^{\circ} \mathrm{C}$ for 10 minutes using Master Cycler Vapo Pro- tect (Eppendorf, Hamburg, Germany). The PCR products underwent NcoI (Thermo Fisher Scientific) digestion which cuts the 5'-CCATGG-3' and 3'-GGTACC-5' sequence. A total reaction volume of $30 \mu \mathrm{L}$ comprised of 17 microlitres of distilled water, 2 $\mu \mathrm{L}$ of $10 \times$ FastDigest Green Buffer, $10 \mu \mathrm{L}(\sim 0.2 \mu \mathrm{g})$ PCR product and $1 \mu \mathrm{L}$ FastDigest NcoI enzyme were mixed together and centrifuged briefly. The reaction mixture was then incubated at $37^{\circ} \mathrm{C}$ for 10 minutes. Ten microliters of this reaction mixture was loaded directly into the gel as the FastDigest Green Buffer can be used as an electrophoresis loading buffer. Electrophoresis of digested product was performed on $2.5 \%$ agarose gel which stained with SYBR Safe DNA gel stain at $80 \mathrm{~V}$ for 50 minutes.

\section{Statistical analysis}

The genotype distributions and allele frequencies was estimated using chi-square test or Fisher exact test to analyse the association between these genepolymorphisms and disease. Multiple Logistic Regression analysis was carried out to determine the associations between these gene polymorphisms and factors related to CRS. All data were entered into IBM SPSS ver. 22.0 (IBM Co., Armonk, NY, USA) for statistical analyses. The results were considered as statistically significant if $P$-value was less than 0.05.All statistical analyses were two-sided tests.

\section{RESULTS}

All 96 samples were successfully genotyped for SNPs for both $T N F \alpha-1031$ and TNF $\beta+252$ genes. Homozygous wild-type (TT) produced single $270 \mathrm{bp}$ fragment and heterozygous mutanttype (TC) yielded three fragments of $270 \mathrm{bp}, 159 \mathrm{bp}$, and 111 


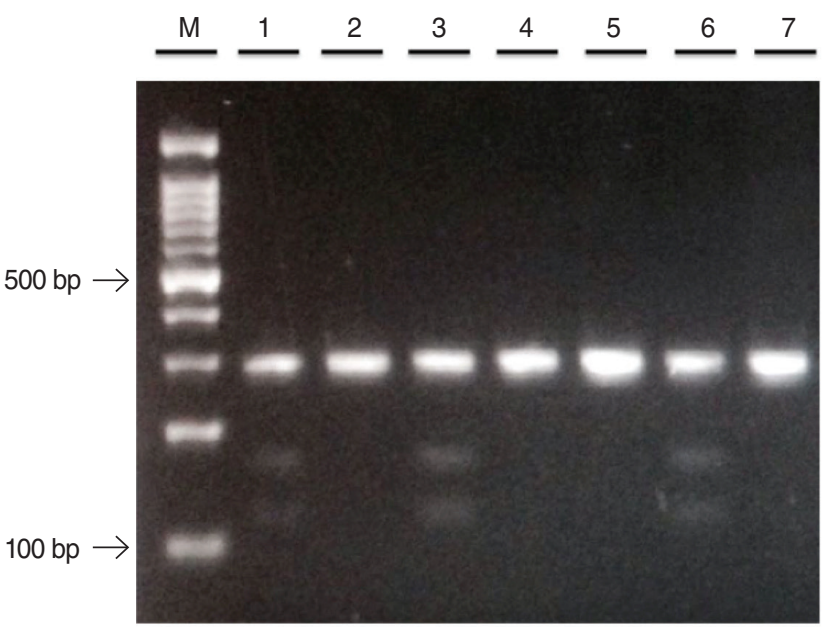

Fig. 1. A restriction fragment length polymorphism analysis of tumor necrosis factor-alpha-1031 gene. Lane 2, 4, 5, and 7: homozygous wild-type (TT); lane 1, 3, and 6: heterozygous mutant-type (TC); M: 100 bp DNA ladder.

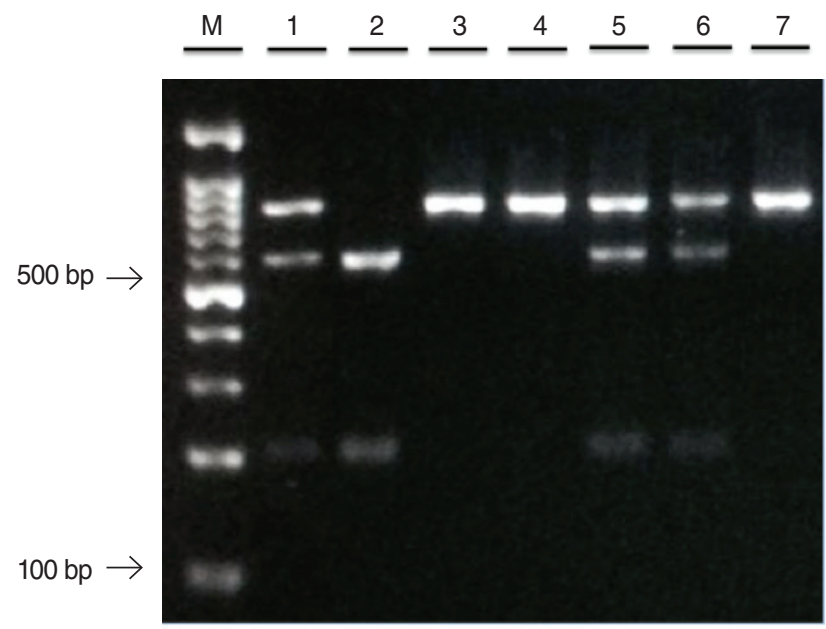

Fig. 2. A restriction fragment length polymorphism analysis of tumor necrosis factor-beta+252 gene. Lane 3, 4, and 7: homozygous wildtype (AA); lane 1, 5, and 6: heterozygous mutant-type (AG); lane 2: homozygous mutant-type (GG); M: 100 bp DNA ladder.

Table 2. Genotype distributions and allele frequencies of TNF $\alpha-1031$ among CRS participants and controls as well as CRSsNP and CRSwNP

\begin{tabular}{|c|c|c|c|c|c|c|}
\hline$T N F \alpha-1031$ & CRS & Control & $P$-value & CRSsNP & CRSwNP & $P$-value \\
\hline Genotype & & & 0.283 & & & 0.768 \\
\hline$\pi$ & $29(60.4)$ & $34(70.8)$ & & $15(62.5)$ & $14(58.3)$ & \\
\hline $\mathrm{TC}$ & 19 (39.6) & 14 (29.2) & & $9(37.5)$ & $10(41.7)$ & \\
\hline Allele & & & 0.339 & & & 0.797 \\
\hline $\mathrm{T}$ & 77 (80.2) & $82(85.4)$ & & $39(81.2)$ & 38 (79.2) & \\
\hline C & 19 (19.8) & $14(14.6)$ & & $9(18.8)$ & $10(20.8)$ & \\
\hline
\end{tabular}

Values are presented as number (\%).

TNF, tumor necrosis factor; CRS, chronic rhinosinusitis; CRSsNP, chronic rhinosinusitis without nasal polyp; CRSwNP, chronic rhinosinusitis with nasal polyp; TT, homozygous wild-type; TC, heterozygous mutant-type; T, thymine; C, cytosine.

Table 3. Associations of TNF $\alpha-1031$ polymorphisms with factors related to CRS adjusted for atopy, asthma and ASA intolerance

\begin{tabular}{lcccccc}
\hline Variable & $T$ (yes/no) & TC (yes/no) & Crude OR $(95 \% \mathrm{Cl})$ & $P$-value & Adjusted OR $(95 \% \mathrm{Cl})^{\mathrm{a})}$ & $P$-value \\
\hline Atopy & $22 / 7$ & $9 / 10$ & $3.49(1.01-12.05)$ & 0.048 & $3.66(1.03-13.06)$ & 0.045 \\
Asthma & $9 / 20$ & $5 / 14$ & $1.37(0.38-4.89)$ & 0.626 & $0.92(0.24-3.62)$ & 0.910 \\
ASA intolerance & $1 / 28$ & $2 / 17$ & $0.33(0.03-3.87)$ & 0.376 & $0.27(0.02-3.67)$ & 0.327 \\
\hline
\end{tabular}

TNF, tumor necrosis factor; CRS, chronic rhinosinusitis; ASA, acetylsalicylic acid; OR, odds ratio; $\mathrm{Cl}$, confidence interval.

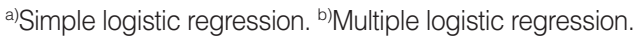

bp as shown in Fig. 1. The homozygous mutant-type (CC) was not detected in both CRS and controls groups. The genotype distributions and allele frequencies for $T N F \alpha-1031$ are presented in Table 2. The TT genotype was slightly higher in control as compared to CRS participants while the TC genotype was more predominant in CRS. As for allele frequency, $\mathrm{T}$ allele appeared slightly higher in control group as compared to CRS but the C allele revealed slightly lower preponderance in control group. However, neither genotype and allele frequencies exhibit significant associations between CRS and healthy controls. Following multivariate analysis, significant association was observed between $T N F \alpha-1031$ gene polymorphisms and CRS with atopy but lack of associations were seen in CRS with asthma and ASA intolerance as shown in Table 3.

Three genotypes of $T N F \beta+252$ polymorphisms were demonstrated in Fig. 2. Homozygous wild-type (AA) produced single fragment of $740 \mathrm{bp}$, heterozygous mutant-type (AG) yielded 3 fragments of $740 \mathrm{bp}, 555 \mathrm{bp}$, and $185 \mathrm{bp}$ while homozygous mutant-type (GG) showed 2 fragments of $555 \mathrm{bp}$ and $185 \mathrm{bp}$. The genotype and allele frequencies were homogenously distributed among CRS and control groups. There was no significant difference obtained for $T N F \beta+252$ genotypes distributions and allele frequencies between CRS and control as shown in Table 4 . Table 5 demonstrates associations between TNF $\beta+252$ gene 
Table 4. Genotype distributions and allele frequencies of TNF $\beta+252$ among CRS participants and controls as well as CRSsNP and CRSwNP

\begin{tabular}{|c|c|c|c|c|c|c|}
\hline$T N F \beta+252$ & CRS & Control & $P$-value & CRSsNP & CRSWNP & $P$-value \\
\hline Genotype & & & 0.302 & & & 0.832 \\
\hline AA & $17(35.4)$ & 15 (31.3) & & $9(37.5)$ & 8 (33.3) & \\
\hline$A G$ & $24(50.0)$ & $30(62.5)$ & & $11(45.8)$ & $13(54.2)$ & \\
\hline $\mathrm{GG}$ & $7(14.6)$ & $3(6.2)$ & & $4(16.7)$ & $3(12.5)$ & \\
\hline Allele & & & 0.767 & & & 0.873 \\
\hline A & $58(60.4)$ & $60(62.5)$ & & $29(60.4)$ & $29(60.4)$ & \\
\hline$G$ & 38 (39.6) & $36(37.5)$ & & 19 (39.6) & 19 (39.6) & \\
\hline
\end{tabular}

Values are presented as number (\%).

TNF, tumor necrosis factor; CRS, chronic rhinosinusitis; CRSsNP, chronic rhinosinusitis without nasal polyp; CRSwNP, chronic rhinosinusitis with nasal polyp; AA, homozygous wild-type; AG, heterozygous mutant-type; GG, homozygous mutant-type; A, adenine; G, guanosine.

Table 5. Associations of TNF $\beta+252$ polymorphisms with factors related to CRS adjusted for atopy, asthma and ASA intolerance

\begin{tabular}{lcccccc}
\hline Variable & $\mathrm{AA}(\mathrm{yes} / \mathrm{no})$ & $\mathrm{AG} \& \mathrm{GG}($ yes/no) & Crude OR $(95 \% \mathrm{Cl})$ & $P$-value & Adjusted OR $(95 \% \mathrm{Cl})^{\mathrm{a})}$ & $P$-value \\
\hline Atopy & $11 / 7$ & $20 / 10$ & $0.79(0.23-2.65)$ & 0.697 & $0.81(0.24-2.80)$ & 0.741 \\
Asthma & $5 / 13$ & $9 / 21$ & $0.90(0.25-3.27)$ & 0.870 & $0.66(0.17-2.59)$ & 0.556 \\
ASA intolerance & $2 / 16$ & $1 / 29$ & $3.63(0.31-43.15)$ & 0.308 & $4.30(0.34-55.22)$ & 0.262 \\
\hline
\end{tabular}

TNF, tumor necrosis factor; CRS, chronic rhinosinusitis; ASA, acetylsalicylic acid; OR, odds ratio; Cl, confidence interval; AA, homozygous wild-type; AG, heterozygous mutant-type; GG, homozygous mutant-type.

a) Simple logistic regression. ${ }^{b}$ Multiple logistic regression.

polymorphisms and factors related to CRS. However, none of these variables show any significant associations with $T N F \beta+252$ gene polymorphims.

\section{DISCUSSION}

In this study, the statistical analysis was unable to demonstrate significant association of $T N F \alpha-1031$ gene polymorphisms between CRS participants' genotype distribution in comparison to healthy controls. Similarly, the allele frequency of $T N F \alpha-1031$ gene did not show any significant associations between CRS and control group. The lack of these associations could be contributed by the fact that SNPs at TNF $\alpha$ polymorphic site are more responsible for genetic markers rather than disease association due to its proximity with polymorphic region of major histocompatibility complex class III at chromosome 6 [16].

In this study, we did not observe any statistically significant difference in genotype distribution as well as allele frequency of $T N F \alpha-1031$ gene polymorphisms between CRSsNP and CRSwNP despite different inflammatory events and clinical course of these 2 conditions [17]. To date, there is no single study attempted to establish the association between TNF $\alpha$ gene between CRSsNP and CRSwNP. This finding suggests that TNF is part of the inflammatory cascade in both CRSsNP and CRSwNP even though the pathogenesis of these 2 conditions is different.

The most striking observation in our study was the statistically significant difference between $T N F \alpha-1031$ gene polymorphisms and CRS participants who exhibit atopy after adjusted for asthma and ASA intolerance with $P$-value of 0.037 . This data showed that TT genotype of $T N F \alpha-1031$ gene increase risk of CRS susceptibility by 3.66-fold in CRS participants with atopy. In contrast, CRS participants with asthma and ASA intolerance were not statistically significant with $T N F \alpha-1031$ gene polymorphisms.

As for $T N F \beta+252$ gene polymorphisms, there was no statistically significant associations observed between CRS and healthy individuals. Similarly, when we took into consideration the related factors of CRS, which are atopy, asthma and ASA intolerance on multiple logistic regression analyses, none of these variables show significant associations between $T N F \beta+252$ gene polymorphisms with CRS.

As per the literature search, this is the first research to establish the potential role of $T N F \alpha-1031$ in CRS. To the best of our knowledge, our study provides the first associative evidence of $T N F \alpha-1031$ gene polymorphisms in CRS patient with atopy in Southeast Asia region. Atopy does modulate more immune response and therefore, CRS patients with atopy have tendency to develop more severe disease manifestation. Literatures have also shown that CRS with atopy associated with more severe computed tomography findings as well as increase need for surgical intervention [18].

Complex and multifactorial processes in the pathogenesis of CRS might contribute these contradicting results. The pathogenesis of CRS is affected by interplay between the immunologic processes, environmental exposure and appropriate management delivered to the patients [19]. Although it is difficult to establish the reason behind these findings, the environmental factor may confound the genetic association of CRS in different geographical areas [20]. The environmental factor in our region which is the tropical rainforest climate might be different from 
those observed in other studies. It is one of the potential risk factors for atopy and thus, worsens the CRS in atopic patient.

There are few genetic studies that attempted to clarify the role of TNF $\alpha$ gene polymorphisms in the pathogenesis of CRS at other promoter regions in chromosome 6 . Several lines of evidence suggested that $T N F \alpha-308$ and $T N F \alpha-238$ in the TNF $\alpha$ promoter regions are the SNPs frequently being studied in CRS. Some studies appeared to support the relationship of $T N F \alpha$ gene polymorphisms with CRS [21-23]. However, several other studies could not replicate such associations [13,24,25].

In this study, we could not produce any significant associations of TNFo-1031 gene polymorphisms in CRS participants with asthma and ASA intolerance. This finding is contradicting with previous report in Turkish population where TNF $\alpha-308$ gene polymorphisms were associated with nasal polyps patients with atopy and ASA intolerance [2]. Another study by Szabo et al. [26] concluded that $T N F \alpha-308$ gene polymorphisms was a predictive risk for the disease development in CRS patients that have nasal polyps with ASA intolerance. In a more recent study done among Romanian asthmatic patients with nasal polyposis reported that $T N F \alpha-857$ gene polymorphisms was significantly associated in this group of patients [27].

Although the role of $T N F \beta+252$ gene polymorphism in CRS is not widely studied before, we attempted to establish its role in this case control study. However, this current report is unable to demonstrate any significant difference of genotype and allele frequencies of $T N F \beta+252$ polymorphisms between CRS participants and healthy controls. The lack of association between this gene and CRS is inconsistent with previous findings [13]. It had been shown that genetic diversity among different populations might influence susceptibility to particular diseases in closed ethnic groups [28].

There is lack of association of TNF $\beta+252$ gene polymorphisms between CRSsNP and CRSwNP participants in this study. Various proinflammatory cytokines play roles in inducing chronic inflammation in both CRSsNP and CRSwNP [29]. Therefore, further molecular analysis is warranted since it seems unlikely that any single proinflammatory cytokine would completely explain the susceptibility towards CRS.

To date, there was no research done to determine the association between $T N F \beta+252$ gene polymorphisms and factors related to CRS. Although the influence of TNF $\beta+252$ gene polymorphisms in CRS patients with asthma is still unclear, its role in asthmatic patients has been established previously [30]. Failure to obtain this association might need further stratification of the clinical parameters in larger sample size.

The effects of cytokine gene polymorphisms in the pathogenesis of CRS are still unclear until now. Our result supports the hypothesis that SNPs in proinflammatory cytokines influenced the susceptibility to CRS in our population and would contribute to better understanding of the pathogenesis that underlie CRS. Although $T N F \alpha-1031$ and $T N F \beta+252$ gene polymor- phisms did not confer any genetic susceptibility to CRS as compared to healthy controls, we found that $T N F \alpha-1031$ gene polymorphisms was significantly associated with CRS participants with atopy. This findings are hoping to produce a change in the current clinical paradigm of CRS. First, we would like to suggest that $T N F \alpha-1031$ gene might be one of the key players in the pathogenesis of CRS with atopy. Besides, CRS patients with atopy are expected to have clinical benefit from the administration of $T N F \alpha$ antagonist in the future.

In this present study, our data propose that $T N F \alpha-1031$ and $T N F \beta+252$ gene polymorphisms did not confer any genetic susceptibility to CRS as compared to healthy controls even though the role of TNF as proinflammatory cytokine in CRS is well established in the literature. However, we found that TNF $\alpha-1031$ gene polymorphisms was significantly associated with CRS participants with atopy. Based on our finding, we would like to draw the possibility of $T N F \alpha-1031$ gene playing a major role in the pathogenesis of CRS. This result may lead to better understanding of genetic basis of CRS, genetic medicine as well as improving health outcomes for patients in the future.

\section{CONFLICT OF INTEREST}

No potential conflict of interest relevant to this article was reported.

\section{REFERENCES}

1. Hastan D, Fokkens WJ, Bachert C, Newson RB, Bislimovska J, Bockelbrink A, et al. Chronic rhinosinusitis in Europe: an underestimated disease: a GA²LEN study. Allergy. 2011 Sep;66(9):1216-23.

2. Pearlman AN, Chandra RK, Chang D, Conley DB, Tripathi-Peters A, Grammer LC, et al. Relationships between severity of chronic rhinosinusitis and nasal polyposis, asthma, and atopy. Am J Rhinol Allergy. 2009 Mar-Apr;23(2):145-8.

3. Chen Y, Dales R, Lin M. The epidemiology of chronic rhinosinusitis in Canadians. Laryngoscope. 2003 Jul;113(7):1199-205.

4. Johansson L, Akerlund A, Holmberg K, Melen I, Bende M. Prevalence of nasal polyps in adults: the Skovde population-based study. Ann Otol Rhinol Laryngol. 2003 Jul;112(7):625-9.

5. Settipane GA. Epidemiology of nasal polyps. Allergy Asthma Proc. 1996 Sep-Oct;17(5):231-6.

6. Aggarwal BB, Gupta SC, Kim JH. Historical perspectives on tumor necrosis factor and its superfamily: 25 years later, a golden journey. Blood. 2012 Jan;119(3):651-65.

7. Brooks LD. SNPs: why do we care? In: Kwok PY, editor. Single nucleotide polymorphisms: methods and protocols. Totowa (NJ): Humana Press; 2003. p. 1-14.

8. Qidwai T, Khan F. Tumour necrosis factor gene polymorphism and disease prevalence. Scand J Immunol. 2011 Dec;74(6):522-47.

9. Sashio H, Tamura K, Ito R, Yamamoto Y, Bamba H, Kosaka T, et al. Polymorphisms of the TNF gene and the TNF receptor superfamily member 1B gene are associated with susceptibility to ulcerative colitis and Crohn's disease, respectively. Immunogenetics. 2002 Mar; 53(12):1020-7. 
10. Li HQ, Li Z, Liu Y, Li JH, Dong JQ, Gao JR, et al. Association of238G/A and -857C/T polymorphisms of tumor necrosis factor-alpha gene promoter region with outcomes of hepatitis $\mathrm{B}$ virus infection. Biomed Environ Sci. 2006 Apr;19(2):133-6.

11. Oregon-Romero E, Vazquez-Del Mercado M, Ruiz-Quezada SL, Navarro-Hernandez RE, Rangel-Villalobos $\mathrm{H}$, Martinez-Bonilla $\mathrm{G}$, et al. Tumor necrosis factor alpha-308 and -238 polymorphisms in rheumatoid arthritis: association with messenger RNA expression and sTNF-alpha. J Investig Med. 2008 Oct;56(7):937-43.

12. Seymour HE, Worsley A, Smith JM, Thomas SH. Anti-TNF agents for rheumatoid arthritis. Br J Clin Pharmacol. 2001 Mar;51(3):201-8.

13. Takeuchi K, Majima Y, Sakakura Y.Tumor necrosis factor gene polymorphism in chronic sinusitis. Laryngoscope. 2000 Oct;110(10 Pt 1): 1711-4.

14. Fokkens WJ, Lund VJ, Mullol J, Bachert C, Alobid I, Baroody F, et al. EPOS 2012: European position paper on rhinosinusitis and nasal polyps 2012: a summary for otorhinolaryngologists. Rhinology. 2012 Mar;50(1):1-12.

15. Bonyadi M, Abdolmohammadi R, Jahanafrooz Z, Somy MH, Khoshbaten M. TNF-alpha gene polymorphisms in Iranian Azari Turkish patients with inflammatory bowel diseases. Saudi J Gastroenterol. 2014 Mar-Apr;20(2):108-12.

16. Daly AK, Day CP. Candidate gene case-control association studies: advantages and potential pitfalls. Br J Clin Pharmacol. 2001 Nov;52 (5):489-99.

17. HuvenneW, van Bruaene N, Zhang N, van ZeleT, Patou J, Gevaert P, et al. Chronic rhinosinusitis with and without nasal polyps: what is the difference? Curr Allergy Asthma Rep. 2009 May;9(3):213-20.

18. Shkoukani MA, Krouse JH. The role of atopy and asthma status in chronic rhinosinusitis in adults. J Otol Rhinol. 2013:2(3). https://doi. org/10.4172/2324-8785.1000122

19. Hamilos DL. Chronic rhinosinusitis: epidemiology and medical management. J Allergy Clin Immunol. 2011 Oct;128(4):693-707.

20. Oakley GM, Curtin K, Orb Q, Schaefer C, Orlandi RR, Alt JA. Familial risk of chronic rhinosinusitis with and without nasal polyposis: genetics or environment. Int Forum Allergy Rhinol. 2015 Apr;5(4): 276-82.
21. Erbek SS, Yurtcu E, Erbek S, Atac FB, Sahin FI, Cakmak O. Proinflammatory cytokine single nucleotide polymorphisms in nasal polyposis. Arch Otolaryngol Head Neck Surg. 2007;133(7):705-9.

22. Bernstein JM, Anon JB, Rontal M, Conroy J, Wang C, Sucheston L. Genetic polymorphisms in chronic hyperplastic sinusitis with nasal polyposis. Laryngoscope. 2009 Jul;119(7):1258-64.

23. Batikhan H, Gokcan MK, Beder E, Akar N, Ozturk A, Gerceker M. Association of the tumor necrosis factor-alpha -308 G/A polymorphism with nasal polyposis. Eur Arch Otorhinolaryngol. 2010 Jun; 267(6):903-8.

24. Fajardo-Dolci G, Solorio-Abreu J, Romero-Alvarez JC, Zavaleta-Villa B, Cerezo-Camacho O, Jimenez-Lucio R, et al. DQA1 and DQB1 association and nasal polyposis. Otolaryngol Head Neck Surg. 2006 Aug;135(2):243-7.

25. Mfuna Endam L, Cormier C, Bosse Y, Filali-MouhimA, Desrosiers M. Association of IL1A, IL1B, and TNF gene polymorphisms with chronic rhinosinusitis with and without nasal polyposis: a replication study. Arch Otolaryngol Head Neck Surg. 2010 Feb;136(2):187-92.

26. Szabo K, Kiricsi A, Revesz M, Vona I, Szabo Z, Bella Z, et al. The $-308 \mathrm{G}>\mathrm{A}$ SNP of TNFA is a factor predisposing to chronic rhinosinusitis associated with nasal polyposis in aspirin-sensitive Hungarian individuals: conclusions of a genetic study with multiple stratifications. Int Immunol. 2013 Jun;25(6):383-8.

27. Berghea EC, Popa OM, Meirosu M, Popa LO, Bara C, Bumbacea RS. Association of TNF-alpha gene polymorphism with nasal polyposis in Romanian asthmatic patients. Rom J Rhinol. 2014 Sep;4(15):14955.

28. Bohonak AJ. Genetic drift in human populations. In: Encyclopedia of life sciences. Chichester, UK: John Wiley \& Son; 2008. http://doi. org/10.1002/9780470015902.a0005440.pub2

29. Pawankar R, Nonaka M. Inflammatory mechanisms and remodeling in chronic rhinosinusitis and nasal polyps. Curr Allergy Asthma Rep. 2007 Jun;7(3):202-8.

30. Jiffri EH, Elhawary NA. Association between $\beta+252$ tumour necrosis factor polymorphism and asthma in western Saudi children. Saudi J Biol Sci. 2011 Jan;18(1):107-11. 